\title{
Poliovirus Receptor 2+ Staining Finding
}

National Cancer Institute

\section{Source}

National Cancer Institute. Poliovirus Receptor 2+ Staining Finding. NCI Thesaurus. Code C131117.

A finding of 2+ staining for poliovirus receptor in a sample. 